University of Wollongong

Research Online

Faculty of Engineering and Information

Faculty of Engineering and Information

Sciences - Papers: Part A

Sciences

$1-1-2015$

\title{
The role of compaction energy on the small strain properties of a compacted silty sand subjected to drying - wetting cycles
}

\author{
A Heitor \\ University of Wollongong, aheitor@uow.edu.au \\ B Indraratna \\ University of Wollongong, indra@uow.edu.au \\ C Rujikiatkamjorn \\ University of Wollongong, cholacha@uow.edu.au
}

Follow this and additional works at: https://ro.uow.edu.au/eispapers

Part of the Engineering Commons, and the Science and Technology Studies Commons

Research Online is the open access institutional repository for the University of Wollongong. For further information contact the UOW Library: research-pubs@uow.edu.au 


\title{
The role of compaction energy on the small strain properties of a compacted silty sand subjected to drying - wetting cycles
}

\begin{abstract}
The elastic properties of a soil are usually investigated to describe its engineering behaviour. The results of previous studies indicate that the effect of changes in suction on the elastic response at a small strain level of soils is significant during compaction and post-compaction periods. Limited efforts have been focused on quantifying those post-compacted responses due to the changes in suction induced by wetting and drying cycles. During their service life, most earth structures experience changes in hydraulic behaviour owing to climatic changes. These seasonal fluctuations in turn impact on the geomechanical performance of compacted soil. In this paper the aspects related to the elastic properties of compacted soils subjected to cycles of drying and wetting are described. Particular emphasis is placed on the effect of compaction energy on the hysteric behaviour (i.e. amplitude of the hysteresis loop) and its dependence on the initial stress state conditions and suction history. The results not only confirm the importance of the current suction in governing the shear and compression velocities and associated moduli, but they also suggest that subsequent drying-wetting cycles or suction history can further induce hysteretic changes, particularly along the wetting paths.

\section{Disciplines}

Engineering | Science and Technology Studies

\section{Publication Details}

Heitor, A., Indraratna, B. \& Rujikiatkamjorn, C. (2015). The role of compaction energy on the small strain properties of a compacted silty sand subjected to drying - wetting cycles. Geotechnique: international journal of soil mechanics, 65 (9), 717-727.
\end{abstract}




\title{
The role of compaction energy on the small strain properties of a compacted silty sand subjected to drying-wetting cycles
}

\author{
A. HEITOR*, B. INDRARATNA* and C. RUJIKIATKAMJORN*
}

\begin{abstract}
The elastic properties of a soil are usually investigated to describe its engineering behaviour. The results of previous studies indicate that the effect of changes in suction on the elastic response at a small strain level of soils is significant during compaction and post-compaction periods. Limited efforts have been focused on quantifying those post-compacted responses due to the changes in suction induced by wetting and drying cycles. During their service life, most earth structures experience changes in hydraulic behaviour owing to climatic changes. These seasonal fluctuations in turn impact on the geomechanical performance of compacted soil. In this paper the aspects related to the elastic properties of compacted soils subjected to cycles of drying and wetting are described. Particular emphasis is placed on the effect of compaction energy on the hysteric behaviour (i.e. amplitude of the hysteresis loop) and its dependence on the initial stress state conditions and suction history. The results not only confirm the importance of the current suction in governing the shear and compression velocities and associated moduli, but they also suggest that subsequent drying-wetting cycles or suction history can further induce hysteretic changes, particularly along the wetting paths.
\end{abstract}

KEYWORDS: compaction; laboratory tests; partial saturation; suction

\section{INTRODUCTION}

Compacted soils are often used as construction materials for earth structures such as retaining walls, dams, foundations, and road and railway embankments, and as such are usually placed and often remain on site under partially saturated conditions. The deformation characteristics of these earth structures under repeated loading (e.g. vibrations caused by traffic of heavy and fast-moving vehicles, heavy earthwork machinery and earthquakes) are generally governed by their elastic properties at a small strain level. These properties can be readily monitored by examining the propagation of the compression and shear waves in the soil. Under a partially saturated condition, the capillary force or suction increases the inter-particle contact forces that in turn contribute to an increase in the stiffness of the soil skeleton. The body waves (i.e. compression and shear waves) propagating through a partially saturated medium are also affected by suction and associated degree of saturation. Compression waves (P-waves) induce the motion of soil grains in the direction of wave propagation and they are mainly affected by the bulk modulus of the medium, which causes them to respond to the variation of the degree of saturation (Inci et al., 2003; George et al., 2009; Barrière et al., 2012). In contrast, shear waves propagate perpendicularly to the direction of their motion, so shear distortion is applied. While it may be thought that shear waves are almost unaffected by the presence of water, intermediate states of saturation can cause a change in shear wave velocity due to the strengthening of the soil skeleton by capillary forces (i.e. Cho \& Santamarina, 2001).

Past research studies have reported that the elastic properties at a small strain level are associated with the soil water retention characteristics (SWRC) (e.g. Cho \& Santamarina,

Manuscript received 23 March 2014; revised manuscript accepted 24 March 2015. Published online ahead of print 22 July 2015.

Discussion on this paper closes on 1 February 2016, for further details see p. ii.

* Centre for Geomechanics and Railway Engineering, Faculty of Engineering and Information Sciences, University of Wollongong, Wollongong, NSW, Australia.
2001; Mancuso et al., 2002). Indeed, a variation of the shear and compression wave velocities ( $V_{\mathrm{s}}$ and $V_{\mathrm{p}}$, respectively) is directly related to the different ranges observed in the SWRC. In particular, inflexions on the shear wave velocity and associated shear stiffness were reported at the air entry value (AEV) and at the transition from funicular to pendular states (e.g. Cho \& Santamarina, 2001). In the low suction range before AEV, the shear modulus increases linearly with suction, after which its increase is predominantly non-linear, mainly due to the distinct hydraulic regulation at the particle level (Mancuso et al., 2002). Similar observations were also reported for a range of different soils by Marinho et al. (1996); Vinale et al. (2001), Inci et al. (2003), Sawangsuriya et al. (2008), Biglari et al. (2012) and Heitor et al. (2012). In addition, Mancuso et al. (2002) and, more recently, Heitor et al. (2013) also reported that the small strain shear modulus depends mainly on the soil fabric derived from compaction, that is, dry and wet of optimum water content particularly in the macroporosity range. Furthermore, this change of soil microstructure caused by variations in the compaction induced states (i.e. water content and compaction effort), often results in distinct mechanical and hydraulic behaviour (Toll \& Ong, 2003; Bagherieh et al., 2009; Sheng \& Zhou, 2011).

The effect of hydraulic hysteresis and suction history on the small strain shear modulus of a completely decomposed tuff has recently been investigated by $\mathrm{Ng}$ et al. (2009) and $\mathrm{Ng} \& \mathrm{Xu}$ (2012). The most striking aspect was observing the hysteresis between the drying and wetting curves, although the size of the loop was small for those soils. The results indicated that at any given suction the shear modulus along the wetting path has a higher value than along the drying path. This is associated with the changes of degree of saturation $\left(S_{\mathrm{r}}\right)$ and the water distribution in the pore structure (menisci) (Cho \& Santamarina, 2001); that is, the lower the $S_{\mathrm{r}}$ the higher the $G_{0}$. Those changes of degree of saturation are caused by the ink-bottle effect (e.g. Lourenco et al., 2012) and the variation in soil structure during drying-wetting cycles (e.g. Cuisinier \& Laloui, 2004). In this context, the ink-bottle effect refers to the soil-water exchange occurring within the soil pores to mimic the existence of large pores connected through smaller pores. The amplitude of the 
hysteresis loop increased as the isotropic confining stresses decreased. George et al. (2009) and Khosravi \& McCartney (2012) reported similar observations for Bonny silt, while $\mathrm{Ng} \& \mathrm{Xu}$ (2012) analysed the experimental data in terms of the current suction ratio (CSR) and reported that the small strain shear modulus $\left(G_{0}\right)$ increased by about $20 \%$ when the CSR increased from 1 to 2 .

While most research studies focused on estimating the change in the elastic properties of compacted soils in relation to $V_{\mathrm{s}}$ and $G_{0}$, limited studies concentrated on the effect of hydraulic hysteresis and additional cycles of wetting and drying using specimens prepared at different compaction energy levels. This is very important given that, during their service life, most earth structures experience changes in hydraulic behaviour and their magnitude is likely to be associated with the compaction energy level imparted during their placement. The magnitude and extent of these changes may be described by the change in the depth of moisture $\left(H_{\mathrm{s}}\right)$ that is affected by climatic fluctuations (Fig. 1). $H_{\mathrm{s}}$ may be estimated based on the Thornthwaite moisture index (TMI) (Thornthwaite, 1948; SA, 1996; Fityus \& Buzzi, 2008). For instance, the TMI distribution for Australian territories gives a $H_{\mathrm{s}}$ ranging from $0.5 \mathrm{~m}$ in coastal continental climates to $4 \mathrm{~m}$ deep in arid climates of central inland and the west coast of Australia (Austroads, 2004).

This paper examines the effect of drying and wetting on the shear and compression wave velocities and corresponding moduli of a compacted silty sand. Different specimens were compacted at the reference optimum moisture content (OMC) and prepared at three different energy levels and then examined. The impact of the suction history was also studied for specimens prepared at the equivalent water content and energy level. The salient aspects in relation to the hysteresis loops, the compaction energy level, the change of CSR, and additional cycles of wetting and drying were also addressed. In addition, this study aims to investigate the role of compaction energy (i.e. increase in roller passes) in the post-compaction hydraulic behaviour of fills having a water content equivalent to that of OMC. The compaction conditions adopted here are aligned with commonly used end-product acceptance criteria (e.g. dry unit weight ratio $\gamma / \gamma_{\max }>0.95$ and water content variation $w-w_{\text {opt }}= \pm 2 \%$, AS 3798 (SA, 2007)).

\section{TESTING PROGRAMME \\ Materials}

The soil for this study was silty sand that was used extensively as embankment fill at Penrith, Australia; it has a plasticity index of $10 \%$, a liquid limit of $25 \cdot 5 \%$ and a specific

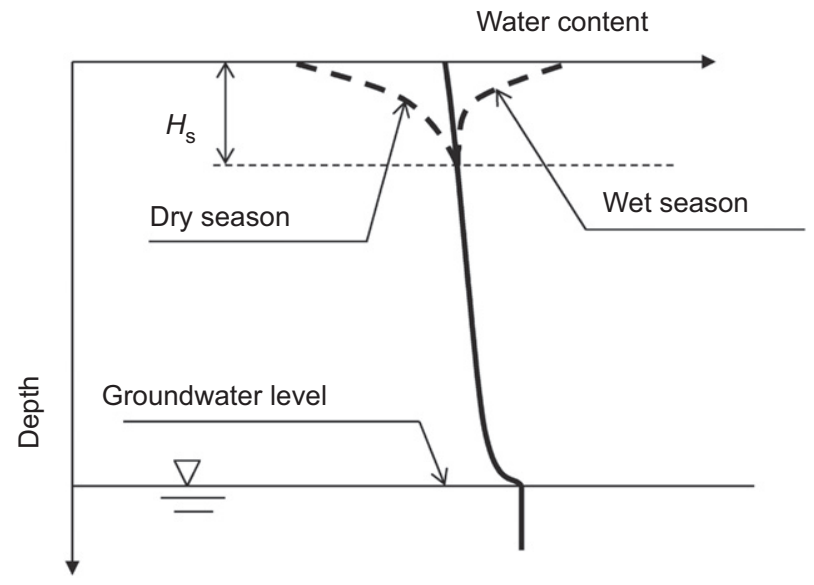

Fig. 1. A profile of the groundwater content exposed to seasonal climatic variations gravity of $2 \cdot 7$, and can thus be classified as SP-SC (Unified Soil Classification System). The particle size distribution of the soil represents $89 \%$ sand, $7 \%$ silt and $4 \%$ clay size fraction (Fig. 2). Before compaction, the sample was air dried before being mixed with the required amount of water using a masonry trowel. Any lumps were disaggregated before placing the mixture in a plastic bag and keeping it overnight under constant temperature and humidity. The compaction characteristics of the sample were established using a standard Proctor compaction test (AS 1289.5.1.1-2003 (SA, 2003)). Three different levels of compaction energy $\left(E_{1}=\right.$ $243 \mathrm{~kJ} / \mathrm{m}^{3}, E_{2}=530 \mathrm{~kJ} / \mathrm{m}^{3}$ and $E_{3}=838 \mathrm{~kJ} / \mathrm{m}^{3}$ corresponding to $41 \%, 89 \%$ and $140 \%$ in relation to the standard Proctor compaction energy level, respectively) were then applied to the $50 \mathrm{~mm}$ diameter by $100 \mathrm{~mm}$ high specimens using the procedures described by Heitor et al. (2013). The three different compaction energy levels adopted for the $50 \mathrm{~mm}$ diameter mould were adjusted to match the target dry unit weights obtained for the traditional Proctor mould for energy levels of $357 \mathrm{~kJ} / \mathrm{m}^{3}, 596 \mathrm{~kJ} / \mathrm{m}^{3}$ and $832 \mathrm{~kJ} / \mathrm{m}^{3}$ following the procedure reported by Sridharan \& Sivapullaiah (2005). Similar procedures have been followed in numerous past studies too, for example, Seed \& Chan (1959), Reddy \& Jagadish (1993) and Tang et al. (2011), among others. These specimen dimensions were selected so the diameter and height of the specimen would minimise the near-field effects (Leong et al., 2005). To illustrate the compaction behaviour, the compaction curves obtained for all energy levels are plotted in Fig. 3. The as-compacted suction (Table 1) was

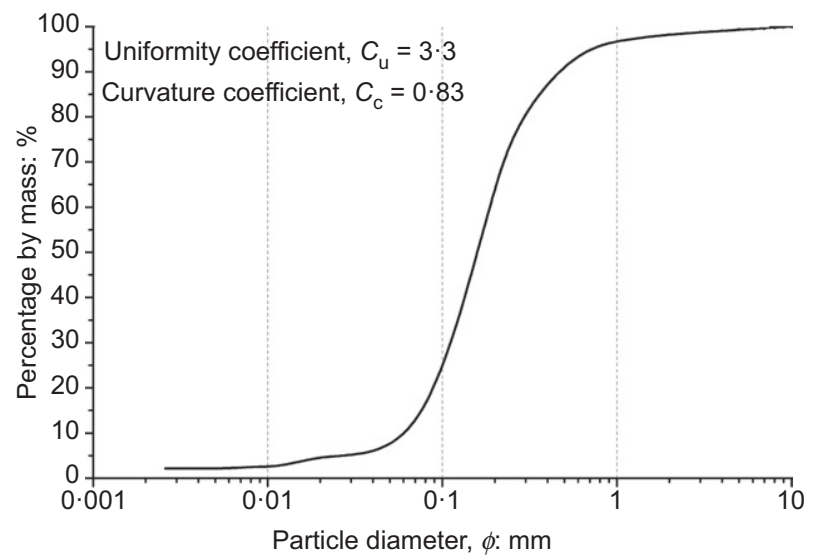

Fig. 2. Particle size distribution of silty sand

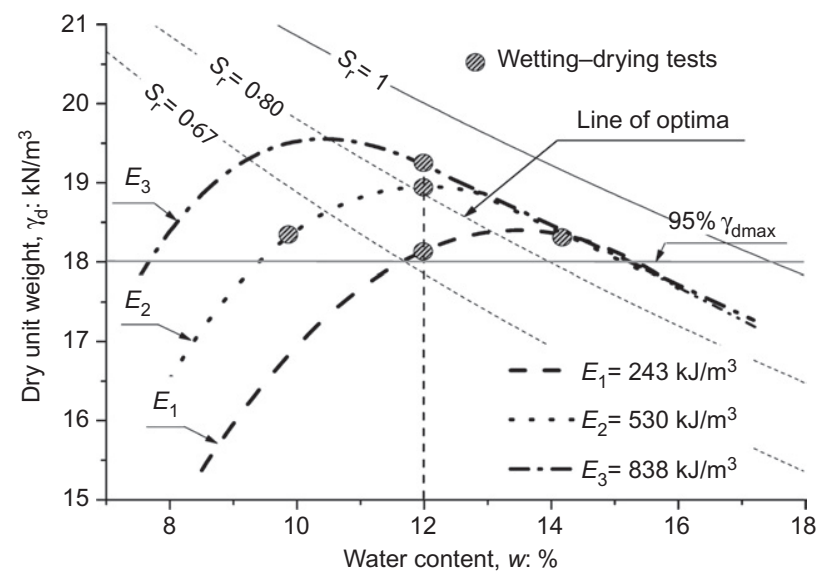

Fig. 3. Compaction curves for the silty sand soil illustrating the three different energy levels adopted 
Table 1. Summary of the initial conditions and testing programme for the post-compacted states wetting-drying series

\begin{tabular}{l|r|c|c|c|c|c|c|c|c}
\hline $\begin{array}{l}\text { Test } \\
\text { no. }\end{array}$ & Test ID & $\begin{array}{c}\text { Energy } \\
\text { level, } E: \\
\mathrm{kJ} / \mathrm{m}^{3}\end{array}$ & $\begin{array}{c}\text { Water } \\
\text { content, } \\
w: \%\end{array}$ & $\begin{array}{c}\text { Dry unit } \\
\text { weight, } \gamma_{\mathrm{d}}: \\
\mathrm{kN} / \mathrm{m}^{3}\end{array}$ & $\begin{array}{c}\text { Dry unit } \\
\text { weight ratio, } \\
\gamma_{\mathrm{d}} / \gamma_{\mathrm{dmax}}\end{array}$ & $\begin{array}{c}\text { Tip-to-tip } \\
\text { distance, } \\
L_{\mathrm{tt}-\mathrm{i}}: \mathrm{mm}\end{array}$ & $\begin{array}{c}\text { Initial } \\
\text { suction, } \\
u_{\mathrm{a}}-u_{\mathrm{w}}: \mathrm{kPa}\end{array}$ & $\begin{array}{c}\text { Net confining } \\
\text { pressure, } \\
p-u_{\mathrm{a}}: \mathrm{kPa}\end{array}$ & $\begin{array}{c}\text { No. of wave } \\
\text { signals to } \\
\text { determine, } V_{\mathrm{s}}, V_{\mathrm{p}}\end{array}$ \\
\hline 1 & $11-12$ & 243 & $11 \cdot 8$ & $18 \cdot 25$ & $0 \cdot 96$ & $98 \cdot 24$ & 74 & 50 & \\
2 & $24-12$ & 530 & $12 \cdot 0$ & $19 \cdot 01$ & 1 & $98 \cdot 37$ & 67 & 50 & 98 \\
3 & $38-12$ & 838 & $12 \cdot 1$ & $19 \cdot 23$ & $1 \cdot 01$ & $99 \cdot 18$ & 65 & 50 & 98 \\
4 & $24-12-2$ & 530 & $12 \cdot 1$ & $18 \cdot 98$ & 1 & $98 \cdot 29$ & 69 & 50 & 98 \\
5 & $24-10$ & 530 & $9 \cdot 8$ & $18 \cdot 45$ & $0 \cdot 97$ & $98 \cdot 83$ & 195 & 50 & 98 \\
6 & $24-14$ & 530 & $14 \cdot 2$ & $18 \cdot 22$ & $0 \cdot 96$ & $98 \cdot 98$ & 15 & 50 & 98 \\
\hline
\end{tabular}

Note: $L_{\mathrm{tt}-\mathrm{i}}$ refers to initial tip-to-tip length and suction represents the pressure differential between the top cap air pressure and bottom pedestal water pressure $\left(u_{\mathrm{a}}-u_{\mathrm{w}}\right)$.

also routinely measured using the filter paper method (ASTM D5298 (ASTM, 2003)) and a small tip tensiometer (ASTM D3404-91 (ASTM, 2004)).

\section{Principles of the bender-extender element test}

There are two types of piezo-ceramic elements, namely $x$-poled and $y$-poled, and they differ according to their direction of polarisation; as the voltage is applied to each piezo-ceramic layer, the $x$-poled and $y$-poled elements either bend or extend if either the S-wave or P-wave is transmitted and/or received, respectively. In the bender-extender elements test a pair of piezo-ceramic elements is used; one is used as the $\mathrm{S}$-wave transmitter and $\mathrm{P}$-wave receiver, while the other is used as the $\mathrm{P}$-wave transmitter and $\mathrm{S}$-wave receiver. A schematic diagram of the bender-extender (BE) elements test set-up is shown in Fig. 4.

The small strain shear modulus $G_{0}$ can be evaluated from the shear wave velocity using the principles of elastic theory, as follows

$$
G_{0}=\frac{\gamma_{\mathrm{b}}}{\boldsymbol{g}} V_{\mathrm{s}}^{2}
$$

where $\gamma_{b}$ is the bulk unit weight $\left(\mathrm{kN} / \mathrm{m}^{3}\right), \boldsymbol{g}$ is the gravity acceleration $\left(\mathrm{m} / \mathrm{s}^{2}\right)$ and $V_{\mathrm{s}}$ is the shear wave velocity $(\mathrm{m} / \mathrm{s})$. For a three-phase mixture, while assuming that the density of the air mass can be omitted (i.e. $\rho_{\mathrm{a}} \cong 0$ ), the bulk unit weight can be calculated based on the porosity $(n)$ and degree of saturation $\left(S_{\mathrm{r}}\right)$, as follows

$$
\gamma_{\mathrm{b}}=(1-n) \gamma_{\mathrm{w}} G_{\mathrm{s}}+S_{\mathrm{r}} n \gamma_{\mathrm{w}}
$$

Similarly, the small strain constrained modulus $\left(M_{0}\right)$ can be evaluated based on the compression wave

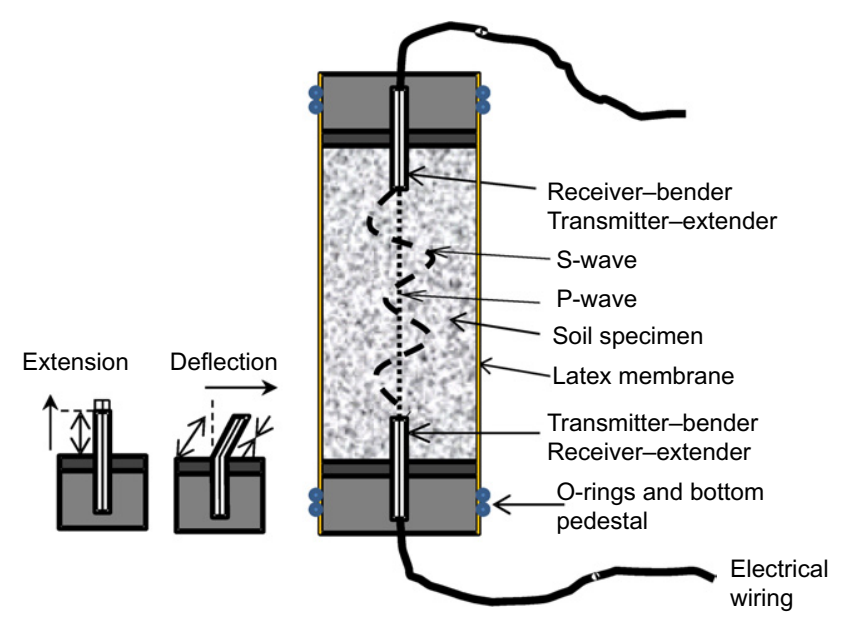

Fig. 4. BE schematic illustration: principles of operation velocity $\left(V_{\mathrm{p}}\right)$ by

$$
M_{0}=\frac{\gamma_{\mathrm{b}}}{\boldsymbol{g}} V_{\mathrm{p}}^{2}
$$

The elastic parameters such as small strain elastic modulus $\left(E_{0}\right)$ and Poisson ratio $(v)$ can also be defined based on the compression and shear wave velocities as follows

$$
\begin{aligned}
& E_{0}=\frac{\left(\gamma_{\mathrm{b}} / \boldsymbol{g}\right) V_{\mathrm{s}}^{2}\left(3 V_{\mathrm{p}}^{2}-4 V_{\mathrm{s}}^{2}\right)}{V_{\mathrm{p}}^{2}-V_{\mathrm{s}}^{2}} \\
& v=\frac{0 \cdot 5 V_{\mathrm{p}}^{2}-V_{\mathrm{s}}^{2}}{V_{\mathrm{p}}^{2}-V_{\mathrm{s}}^{2}}
\end{aligned}
$$

Shear and compression wave velocities $\left(\mathrm{V}_{s}\right.$ and $\left.\mathrm{V}_{p}\right)$

To measure the $V_{\mathrm{p}}$ and $V_{\mathrm{s}}$ of the compacted specimens, a non-destructive technique using a pair of bender-extender elements (BE) was adopted in a standard triaxial apparatus. The $11 \mathrm{~mm} \times 1.6 \mathrm{~mm}$ piezo-eletrical elements were embedded into the triaxial top cap and bottom pedestal, and protruded by $1.7 \mathrm{~mm}$. A schematic diagram of the set-up is shown in Fig. 4. This system could generate and detect compression and shear waves. GDSBES v2.0 software (GDS Instruments) controlled the signal generation, while the data acquisition system had two input channels with 16-bit resolution and a sampling rate of $300-500 \mathrm{kHz}$ to ensure that the resolution of the time and voltage of the input and output signals was adequate.

The BE system can potentially pick up redundant background noise from electrical sources and other sources of ambient residual vibration. The noise is random and its influence can be minimised or eliminated by sampling a larger number of signals and consistently averaging the results. The desired portion of the signal repeats systematically and its amplitude decreases in direct proportion to the number of signals that are averaged and thus the signal-to-noise ratio (SNR) is improved. This procedure is called staking and is qualitatively shown in Fig. 5. The SNR can also be enhanced by increasing the amplitude of the input signal (Leong et al., 2005). It was found that a sinusoidal double amplitude wave of $10 \mathrm{~V}$ and systematically staking 20 sampled signals was enough to reproduce signals that were relatively free of background noise.

One of the difficulties of using bender-extender elements to measure wave velocities is selecting adequate testing variables, including the waveform and testing frequency (Leong et al., 2005; Clayton, 2011). Fig. 6 shows the traces of shear and compression wave velocities obtained in a specimen compacted at $12 \%$ water content and an energy level of $529.5 \mathrm{~kJ} / \mathrm{m}^{3}$ tested with different excitation frequencies. The time domain traces show that at excitation frequencies 


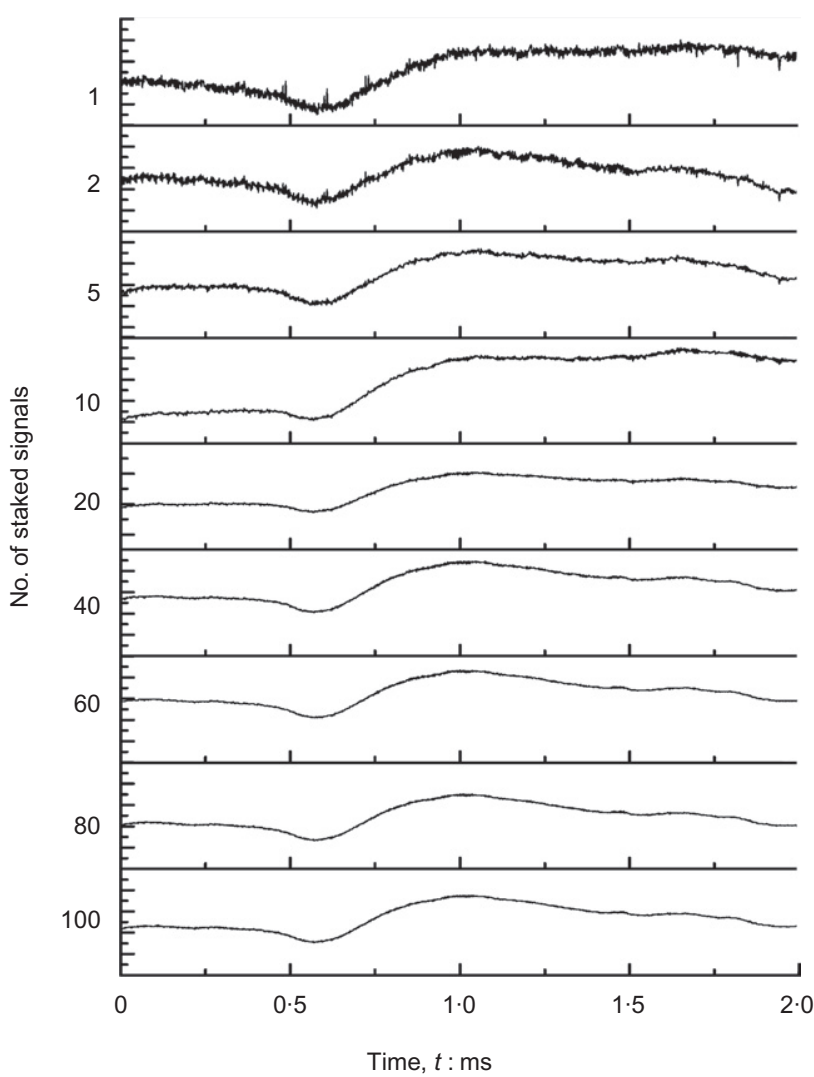

Fig. 5. Shear wave time domain traces for increasing number of staked signals of a specimen prepared at a moisture content of $12 \%$ with compaction energy of $530 \mathrm{~kJ} / \mathrm{m}^{3}$

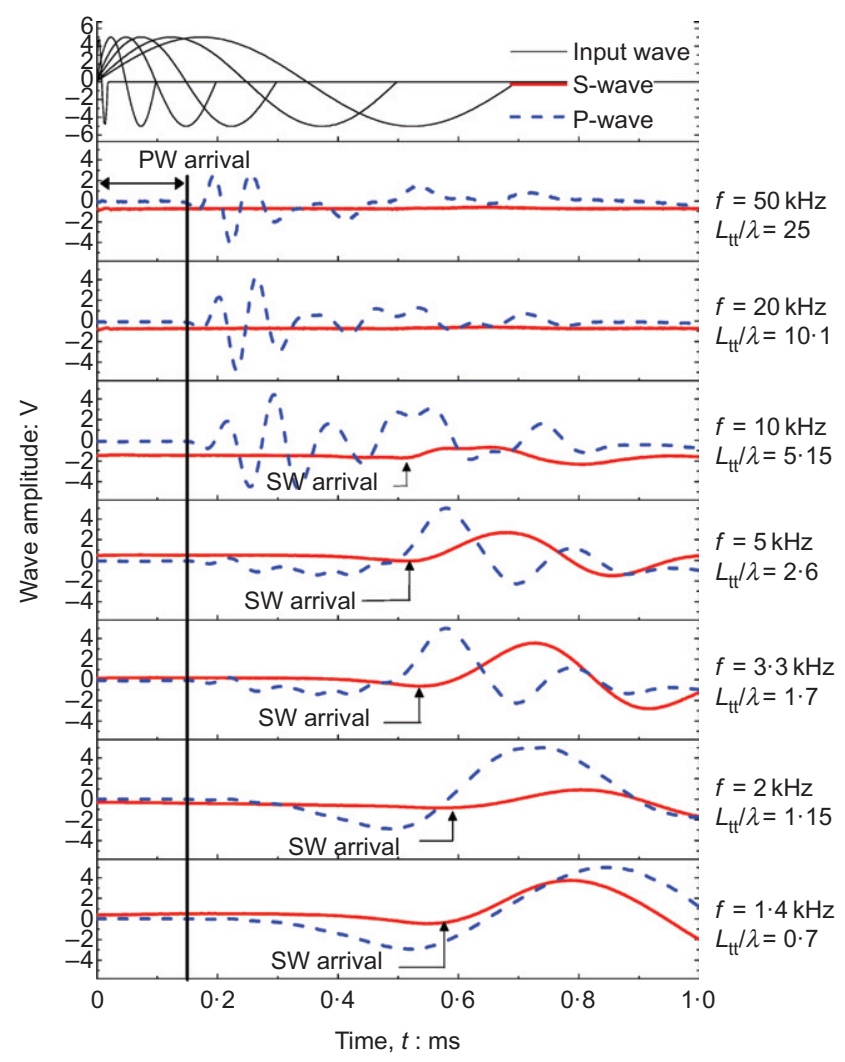

Fig. 6. Typical traces of shear (S-wave (SW)) and compression (P-wave (PW)) wave time domain for different testing frequencies varying from 1.4 to $50 \mathrm{kHz}$ (specimen prepared at a compaction energy level of $530 \mathrm{~kJ} / \mathrm{m}^{3}$ tested under unconfined conditions) above $3.3 \mathrm{~Hz}$, approximately the same travel time was observed, whereas lower values of $1.4 \mathrm{kHz}$ and $2 \mathrm{kHz}$ led to much larger values because of the impact of the near-field component that is associated with the propagation of other signals of opposite polarity (Sanchez-Salinero et al., 1986). Thus, if only the test data collected at low testing frequencies are used to calculate $V_{\mathrm{s}}$, then there is a danger of underestimating the shear wave velocity $\left(V_{\mathrm{s}}\right)$ obtained. The arrival of the compressional wave was determined by examining the point of first deflection in the received signal. This can either be accessed by visual inspection or using an automated procedure that detects small changes in the amplitude of the received signal for cases where visual inspection is difficult (e.g. Leong et al., 2009). In this study it was found that the arrival of the compressional wave is relatively independent of the testing frequency, although the wave propagation mode seems to change for lower excitation frequencies (i.e. $f<5 \mathrm{kHz}$ ). This is possibly associated with the frequency dependence of the two kinds of waves generated during the propagation of compressional waves through solid and fluid in soil matrix (i.e. in-phase wave and out-of-phase wave). The latter tends to be highly attenuated and its effect on the results presented is relatively small.

Unlike the compression wave, the amplitude of the shear wave signal was associated with the excitation frequency, such that as the frequency increased beyond $5 \mathrm{kHz}$, the amplitude of the received signal was significantly reduced (e.g. lower than $2 \mathrm{~V}$, Fig. 6). This is consistent with the findings of Arulnathan et al. (1998), and shows that a decrease in wavelength $(\lambda)$ in relation to the bender element length ratio $\left(l_{\mathrm{b}}\right)$ contributes to the deterioration of the received signals. While it would be preferable to measure the shear wave velocity at higher testing frequencies (larger $L_{\mathrm{tt}} / \lambda$ ratios where $L_{\mathrm{tt}}$ is the length of the wave path), the amplitudes of received signals are often deemed unsuitable to allow for either time or frequency domain analysis. It was found that testing frequencies having a ratio between the wave path length to wavelength $\left(L_{\mathrm{tt}} / \lambda\right)$ exceeding 2 could minimise the effect of the near-field component and warrant the strength of the received signal.

The velocities of the shear and compression waves were computed based on the wave path length $\left(L_{\mathrm{tt}}\right)$ that corresponds to the tip-to-tip distance between the transmitter and receiver, and the travel time $\left(\Delta t_{\mathrm{s}}\right.$ and $\left.\Delta t_{\mathrm{p}}\right)$, as follows

$$
\begin{gathered}
V_{\mathrm{s}}=\frac{L_{\mathrm{tt}}}{\Delta t_{\mathrm{s}}} \\
V_{\mathrm{p}}=\frac{L_{\mathrm{tt}}}{\Delta t_{\mathrm{p}}}
\end{gathered}
$$

The initial tip-to-tip distance was determined based on the total height of the sample, the protruding heights of the bender-extender elements and axial strain during drying-wetting cycles. The travel time of the shear wave $\left(\Delta t_{\mathrm{s}}\right)$ was taken as the time interval to the peak of the first bump, as described by Lee \& Santamarina (2005), or to the first deflection when the first bump was not visible (Fig. 6). The travel time of the compression wave $\left(\Delta t_{\mathrm{p}}\right)$ was taken as the time interval to first deflection (Fig. 6).

\section{Variation in suction during wetting and drying cycles}

Suction was imposed on the specimens by applying a given air pressure by way of a top cap and a given value of water pressure beneath the high air entry value (HAEV) ceramic disc. A pressure controller accurate to $1 \mathrm{~mm}^{3}$ controlled air and water pressures applied to the specimen in a load frame 
triaxial cell, while the HAEV ceramic disc had an air entry value of 15 bar. The water pressure controller had a gauge to measure the volume of water flowing into or out of the specimen as the suction changed. The criterion for equilibrium was based on the rate at which volumes of water exchanged during wetting or drying (Fig. 7), and larger volumes of water were usually exchanged along the drying paths. Fig. 7 includes selected examples of the volume of water exchange for the energy levels considered in this study (i.e. $E_{1}=247 \mathrm{~kJ} / \mathrm{m}^{3}, E_{2}=530 \mathrm{~kJ} / \mathrm{m}^{3}$ and $E_{3}=838 \mathrm{~kJ} / \mathrm{m}^{3}$ ). Indeed, at $E_{1}$ the water exchange during equilibration is much larger than that of $E_{2}$ and $E_{3}$. For instance, when the specimens are dried to a suction level of $50 \mathrm{kPa}$, the volume of water exchanged is $1326 \mathrm{~mm}^{3}, 827 \mathrm{~mm}^{3}$ and $239 \mathrm{~mm}^{3}$ for $E_{1}, E_{2}$ and $E_{3}$. This is mainly associated with the initial soil structure and the void ratio dependency governing the water retention behaviour (e.g. Pham et al., 2005; Tarantino \& Tombolato, 2005). For larger suction levels upon drying, that is, 100 and $150 \mathrm{kPa}$, similar behaviour is observed. In contrast, when the specimens undergo wetting, the water exchange capacity is smaller and typically ranges between 434 and $609 \mathrm{~mm}^{3}$ (see Fig. 7, suction of 50 and $100 \mathrm{kPa}$ ). This is related to the manner in which the water intrudes the pore structure, namely ink-bottle effect (Pham et al., 2005), and this is consistent with the water retention data in Fig. 8. These data clearly demonstrate that the specimens compacted at a relatively low dry unit weight (i.e. larger voids in an aggregated structure) show a larger variation in $S_{\mathrm{r}}$ upon drying and wetting. Different levels of suction or pressure difference $\left(s=u_{\mathrm{a}}-u_{\mathrm{w}}\right)$ were imposed on the specimens throughout the test by adjusting the water backpressure while the air and cell pressures were kept constant (i.e. constant net confining pressure, $p-u_{\mathrm{a}}$ ). In these tests an increment of suction in each stage was $50 \mathrm{kPa}$, while the water pressure was changed at $0 \cdot 16 \mathrm{kPa} / \mathrm{min}$ and kept constant until the end of the equilibration period. Typically, a 48-60 h period was enough for the specimens to reach equilibrium. At every stage the axial displacement was also monitored within $0.001 \mathrm{~mm}$, with a linear variable differential transducer (LVDT); the changes in the axial strain were small, typically within $0 \cdot 01 \%$. The drying and wetting branches of the SWRC within the range of the suction tested could be determined based on the change in the volume of water in each step. At the end of the test the water content of the specimen was determined by the oven dried method and the differences in the water content monitored by the water pressure controller were verified.

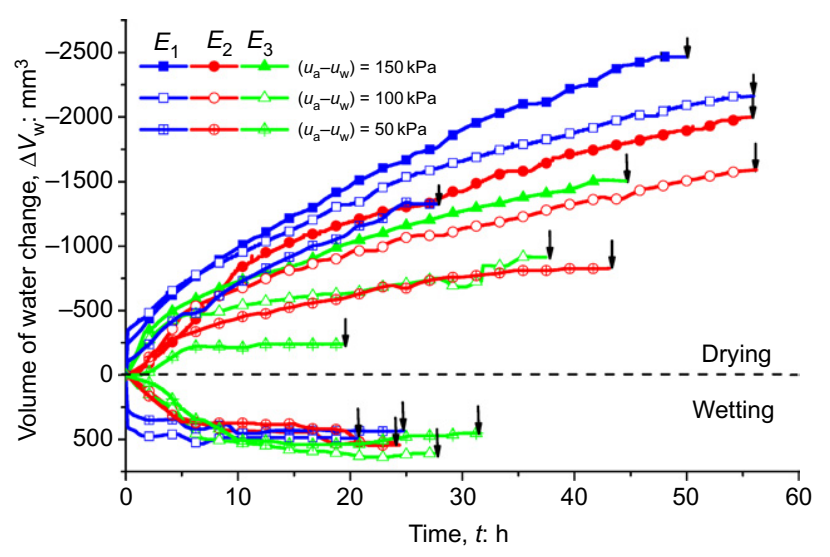

Fig. 7. Example of the variation of the volume of water monitored during equalisation stages for specimens prepared at $w=11.8 \%$ and $E_{1}=243 \mathrm{~kJ} / \mathrm{m}^{3}, w=12 \%$ and $E_{2}=530 \mathrm{~kJ} / \mathrm{m}^{3}$ and $w=12 \cdot 1 \%$ and $E_{3}=838 \mathrm{~kJ} / \mathrm{m}^{3}$ (arrows indicated the equilibrium of the specimens)

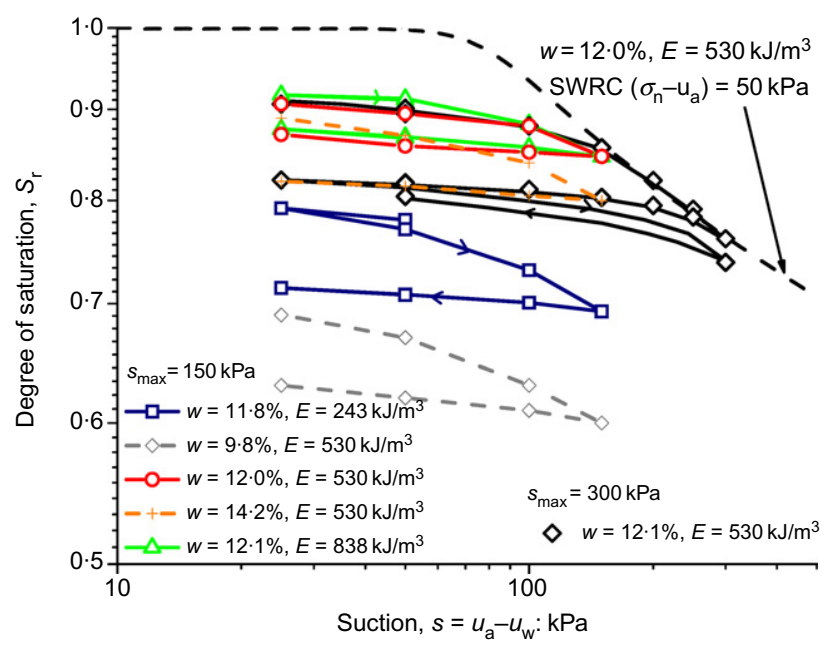

Fig. 8. Water retention data of the drying-wetting cycles of specimens prepared at different energy levels with similar water content $\left(s_{\max }=\right.$ maximum suction)

Figure 8 shows the corresponding water retention data computed based on the volume of water at the end of the equilibrium stages. The SWRC of a specimen compacted at an energy level of $530 \mathrm{~kJ} / \mathrm{m}^{3}$ is given as a reference. For most of the suction levels considered (25 to $150 \mathrm{kPa}$ ), most specimens lay on the scanning curves (i.e. hydraulic states enclosed by the main drying or wetting curves as explained by Tarantino \& Tombolato (2005)), which is basically equivalent to expected field conditions. There was a marked hysteresis along the drying and wetting paths for all four specimens (Table 1). This difference was probably due to a heterogeneous entrapment of water in the soil pore throats (i.e. the ink bottle effect) and different contact angles during drying and wetting processes. Furthermore, the extent of the hysteric response of a specimen prepared at a lower of compaction energy level (i.e. $E=243 \mathrm{~kJ} / \mathrm{m}^{3}$ ) appeared to be larger, and then progressively decreased in those specimens prepared at higher energy levels $\left(E=530 \mathrm{~kJ} / \mathrm{m}^{3}\right.$ and $838 \mathrm{~kJ} / \mathrm{m}^{3}$ ). Thus the hysteric response depends on the initial soil structure and dry unit weight (or associated degree of saturation). Typically the term hydraulic hysteresis is used to describe the variation of degree of saturation between wetting and drying paths of the SWRC for the same suction level (e.g. Pham et al., 2005). In this study, the term small strain hysteresis is used to refer to the variation of $V_{\mathrm{s}}$ and $V_{\mathrm{p}}$ between the drying and wetting paths. The equivalent changes in suction of $25-150 \mathrm{kPa}$ and $25-300 \mathrm{kPa}$ resulted in variations in the water content of $\pm 1 \cdot 0 \%$ and $\pm 1.5 \%$, respectively.

\section{RESULTS AND DISCUSSION \\ Compression and shear wave velocities and associated elastic parameters}

In total, six compacted specimens were tested using bender elements under constant isotropic net confining pressure $\left(p-u_{\mathrm{a}}\right)$ of $50 \mathrm{kPa}$, which was adopted based on an estimation of $H_{\mathrm{s}}$ (approximately $2.5 \mathrm{~m}$ ) for Penrith (Australia), and used for $V_{\mathrm{s}}$ and $V_{\mathrm{p}}$ evaluation. An emphasis was placed on investigating the impact of the level of compaction in the post-compacted small strain behaviour of specimens subjected to drying and wetting. Their initial compaction characteristics and testing conditions selected are given in Table 1. 
The tests were conducted in a load frame based triaxial cell, where $V_{\mathrm{s}}$ and $V_{\mathrm{p}}$ were monitored using bender-extender elements that were cantilevered in the $50 \mathrm{~mm}$ diameter top cap and HAEV bottom pedestal. At each suction step, 14 signals with frequencies of $1 \cdot 4,2,3,5,10,20$ and $50 \mathrm{kHz}$ were analysed to determine the travel time and associated wave velocity. An example of the wave time domain traces during the first drying-wetting cycle tested at $10 \mathrm{kHz}$ is shown in Fig. 9.

The equivalent $L_{\mathrm{tt}} / \lambda$ values monitored during the dryingwetting cycle are also given as a reference. As the suction

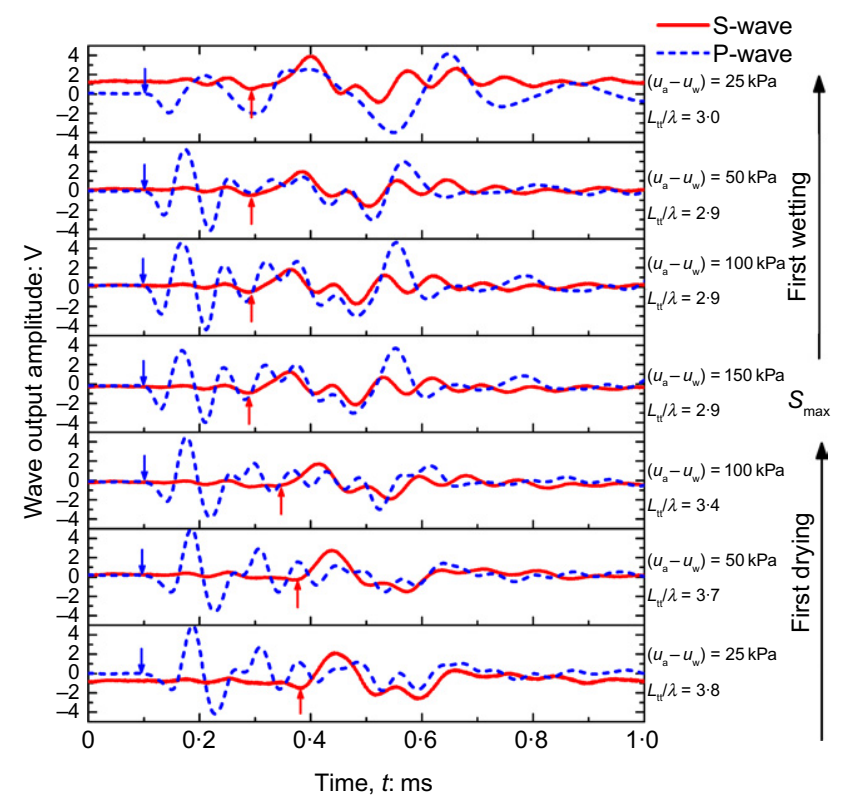

Fig. 9. Typical wave time domain traces during a drying-wetting cycle of a specimen prepared at $w=11 \cdot 8 \%$ and $E=230 \mathrm{~kJ} / \mathrm{m}^{3}$ for a testing frequency of $10 \mathrm{kHz}$ with $L_{\mathrm{tt}} / \lambda>2$

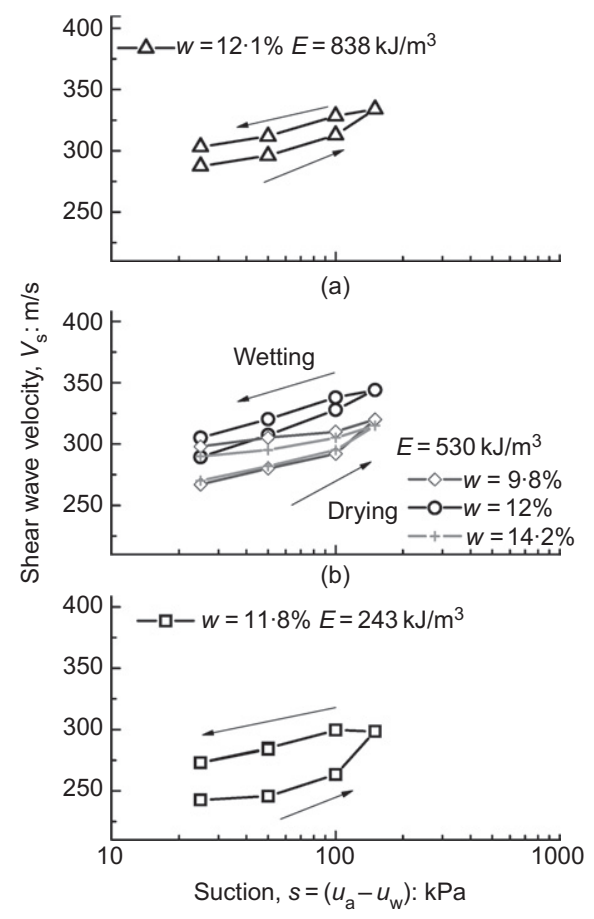

(c) increased on the drying path, the arrival time of both compression and shear waves decreased, which resulted in an increase in the wave velocities. This change was more noticeable in the shear wave time domain traces. On the wetting path there was only slight variation in the velocity of both waves and, although the propagation mode in the first drying path was consistent, it showed some dissimilarity in the following wetting paths.

The variations in the computed shear wave velocity $\left(V_{\mathrm{s}}\right)$ of five specimens with increasing (drying) and decreasing (wetting) suction are depicted in Figs 10(a)-10(c). The most striking aspect is that $V_{\mathrm{s}}$ exhibits hysteric response and had a larger value following the wetting path. This might not correspond to the intuitive behaviour first expected, but it can be associated with the soil-water exchange in soil pores responsible for the hysteretic response seen in the SWRC (Fig. 8). In addition, microstructural studies have reported that the soil fabric during drying is also evolving into a more constricted porosity centred at the microporosity range, although it recovers some of the macroporosity when it is subsequently wetted (Cuisinier \& Laloui, 2004; Monroy et al., 2010). These results are also consistent with the small strain shear modulus studies on decomposed tuff and Bonny silt conducted by $\mathrm{Ng} \& \mathrm{Xu}$ (2012) and Khosravi \& McCartney (2012). In addition, the hysteresis amplitude showed some differences between the five specimens (Figs 10(a)-10(c)). For instance, the specimen compacted at $243 \mathrm{~kJ} / \mathrm{m}^{3}$ with a suction of $25 \mathrm{kPa}$, had a $V_{\mathrm{s}}$ hysteresis amplitude of about $30 \mathrm{~m} / \mathrm{s}$, but at energy $530 \mathrm{~kJ} / \mathrm{m}^{3}$ and $838 \mathrm{~kJ} / \mathrm{m}^{3}$, it was around $24 \mathrm{~m} / \mathrm{s}$ and $16 \mathrm{~m} / \mathrm{s}$, respectively. This difference was probably related to the initial macrostructure of the specimens (e.g. Bagherieh et al., 2009; Heitor et al., 2013). Furthermore, these results seem to suggest that soil compacted under lower energy (i.e. larger percentages of macropores) has a larger $V_{\mathrm{s}}$ hysteresis amplitude in cycles of drying and wetting. For the optimum moisture content of $12 \%\left(E_{2}\right)$, the difference in dry densities between $E_{2}$ and $E_{3}$ is not significant, whereas the dry density of $E_{1}$ is significantly smaller. This is because the soil structure would

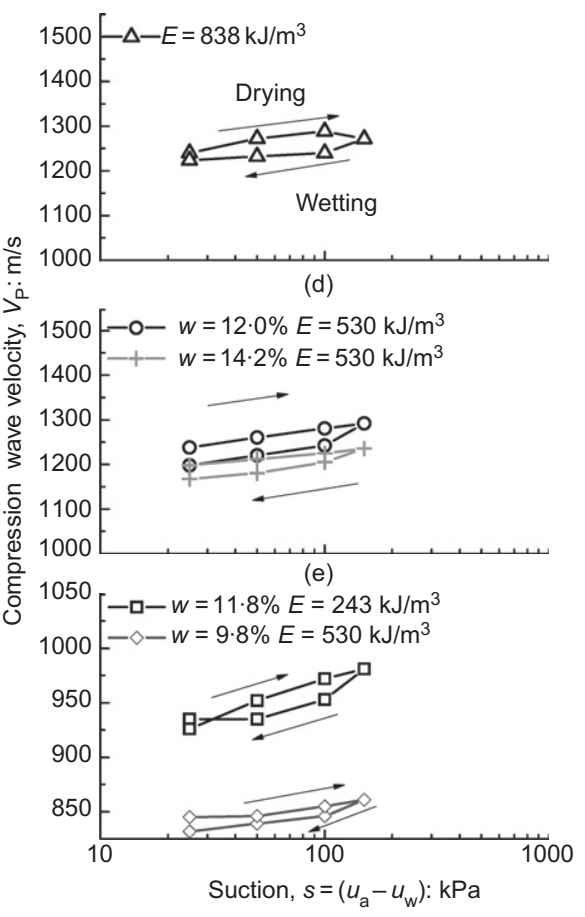

(f)

Fig. 10. Variation of $V_{\mathrm{s}}$ and $V_{\mathrm{p}}$ with suction during a drying-wetting cycle of specimens prepared at energy levels of (a) and (d) $838 \mathrm{~kJ} / \mathrm{m}^{3}$, (b) and (e) $530 \mathrm{~kJ} / \mathrm{m}^{3}$, and (c) and (f) $243 \mathrm{~kJ} / \mathrm{m}^{3}$ 
change from an aggregated macrostructure on the dry side of $\mathrm{OMC}$ (i.e. $E_{1}=243 \mathrm{~kJ} / \mathrm{m}^{3}$ ) to a progressively matrixdominated macrostructure on the wet side of OMC (i.e. $E_{3}=$ $838 \mathrm{~kJ} / \mathrm{m}^{3}$ ). The role of the initial structure and associated porosity should be more influential in determining the size and shape of $V_{\mathrm{s}}$ hysteresis upon drying-wetting cycles, that is, about $V_{\mathrm{s}}=30 \mathrm{~m} / \mathrm{s}, 24 \mathrm{~m} / \mathrm{s}$ and $16 \mathrm{~m} / \mathrm{s}$ for $E_{1}, E_{2}$ and $E_{3}$, respectively (Fig. 10).

For $E_{2}$, the specimens compacted at 2\% dry and 2\% wet of OMC had similar dry unit weights, but clearly the specimen compacted on the wet side of OMC had a degree of saturation approaching $85 \%$ with a corresponding 'ascompacted' suction of $15 \mathrm{kPa}$, whereas the specimen compacted on the dry of optimum (i.e. $S_{\mathrm{r}}<65 \%$ ) sustained an 'as compacted' suction as large as $195 \mathrm{kPa}$. As illustrated in past literature through computed tomography and mercury intrusion techniques, the soil structure would also change from a predominantly aggregated assembly on the dry side of $\mathrm{OMC}$ to a more matrix-dominated macrostructure on the wet side of OMC (e.g. Delage et al., 1996; Monroy et al., 2010).

While the above differences in the 'as-compacted' state govern the small strain behaviour (Heitor et al., 2013), its influence is likely to become smaller when the specimens are subjected to the same suction level during drying and wetting cycles. While the specimen prepared at $w=9.8 \%$ might be expected to exhibit a distinctly different behaviour than that of $w=14 \cdot 2 \%$, the $V_{\mathrm{s}}$ values following the drying path are of similar magnitudes (Fig. 10(b)). This behaviour can be attributed to the inevitable alterations of the soil structure when specimens are brought to the same level of suction (e.g. Koliji et al., 2010). Nevertheless, the influence of the initial structure can still be observed in the $V_{\mathrm{s}}$ hysteresis loop, that is, $31 \mathrm{~m} / \mathrm{s}$ for $w=9 \cdot 8 \%$ and $20 \mathrm{~m} / \mathrm{s}$ for $w=14 \cdot 2 \%$ for suction of $25 \mathrm{kPa}$.

While the two specimens compacted on the dry side of OMC ( $w=9 \cdot 8 \%$ at $E_{2}$ and $w=11 \cdot 8 \%$ at $\left.E_{1}\right)$ are likely to have a similar aggregated macrostructure (Delage et al., 1996), $V_{\mathrm{s}}$ magnitude is larger for the specimen having a higher dry unit weight, although the size of $V_{\mathrm{s}}$ hysteresis in drying and wetting is approximately the same $(\approx 30 \mathrm{~m} / \mathrm{s})$. In contrast, for the two specimens compacted on the wet side of OMC $\left(w=14 \cdot 2 \%, E_{2}\right.$ and $\left.w=12 \cdot 1 \%, E_{3}\right)$ having a matrixdominated macrostructure, $V_{\mathrm{s}}$ magnitude is larger for the specimen having higher dry unit weight $\left(w=12 \cdot 1 \%, E_{3}\right)$, whereas $V_{\mathrm{s}}$ hysteresis amplitude in drying and wetting is $20 \mathrm{~m} / \mathrm{s}$ for $w=14 \cdot 2 \%$ and $16 \mathrm{~m} / \mathrm{s}$ for $w=12 \cdot 1 \%$. This indicates that when the specimens are brought to the same suction level, the $V_{\mathrm{s}}$ magnitude seems to be mainly dependent on their dry unit weights, whereas the $V_{\mathrm{s}}$ hysteresis seems to be influenced by the initial compacted structure. Interestingly, the specimen prepared at $243 \mathrm{~kJ} / \mathrm{m}^{3}$ with a corresponding maximum dry unit weight ratio of $96 \%$, which is just borderline with respect to the common end-production specification of $95 \%$ (AS 3798 (SA, 2007)), had an hysteresis amplitude that was almost twice the one prepared at an equivalent standard Proctor energy $\left(530 \mathrm{~kJ} / \mathrm{m}^{3}\right)$. This indicates that even slight changes in compaction energy along the constant water content paths will have an important impact on the post-compacted response of compacted fills.

The variation of $V_{\mathrm{p}}$ with increasing (drying) and decreasing (wetting) suction for all three specimens is depicted in Figs 10(d)-10(f). Similarly, the compression wave velocity also exhibited hysteresis behaviour between the drying and wetting paths, but unlike $V_{\mathrm{s}}$, the recorded $V_{\mathrm{p}}$ was higher along the drying paths. This was not surprising because the mode in which the waves propagate is different. The compressional wave propagates through both fluid and solid phases and therefore, as the degree of saturation increases or decreases, the wave velocity changes. In wetting and drying cycles for the same suction level, the $V_{\mathrm{p}}$ variation is mainly associated with the amount of water present in the specimen; that is, the higher is the $S_{\mathrm{r}}$ value, the higher the magnitude of $V_{\mathrm{p}}$ is. In contrast, the shear wave velocity propagates only through the soil skeleton. While for fully saturated conditions it is relatively unaffected by the presence of water, under partially saturated conditions, the propagation of shear wave is more complex. Past research studies have shown that the shear wave velocity is sensitive to the degree of saturation (e.g. Cho \& Santamarina, 2001); in other words, the lower is the $S_{\mathrm{r}}$ value, the higher the value of $V_{\mathrm{s}}$ is.

Figures 10(d)-10(f) also illustrates how the initial compaction history affects the $V_{\mathrm{p}}$ hysteresis characteristics. Here the hysteresis amplitude of $V_{\mathrm{p}}$ was relatively independent of the initial compaction energy level, with amplitudes ranging from 46 to $52 \mathrm{~m} / \mathrm{s}$ for 230 and $838 \mathrm{~kJ} / \mathrm{m}^{3}$, respectively.

To simulate a different suction history, Fig. 11 shows the $V_{\mathrm{s}}$ and $V_{\mathrm{p}}$ results of an additional specimen prepared at an equivalent standard compaction energy level which was subjected higher suction (up to $300 \mathrm{kPa}$ ). Similarly with Fig. 10, both $V_{\mathrm{s}}$ and $V_{\mathrm{p}}$ showed a hysteretic response on the wetting paths, but while the $V_{\mathrm{s}}$ and $V_{\mathrm{p}}$ values recovered when the soil was subjected to a second cycle of drying at $300 \mathrm{kPa}$, in the subsequent wetting cycle both $V_{\mathrm{s}}$ and $V_{\mathrm{p}}$ again displayed hysteretic behaviour. The shear wave velocity showed an increase of $17 \mathrm{~m} / \mathrm{s}$, whereas the compressional wave velocity increased $30 \mathrm{~m} / \mathrm{s}$. Both $V_{\mathrm{s}}$ and $V_{\mathrm{p}}$ would be expected to show slight hysteresis on both paths, similar

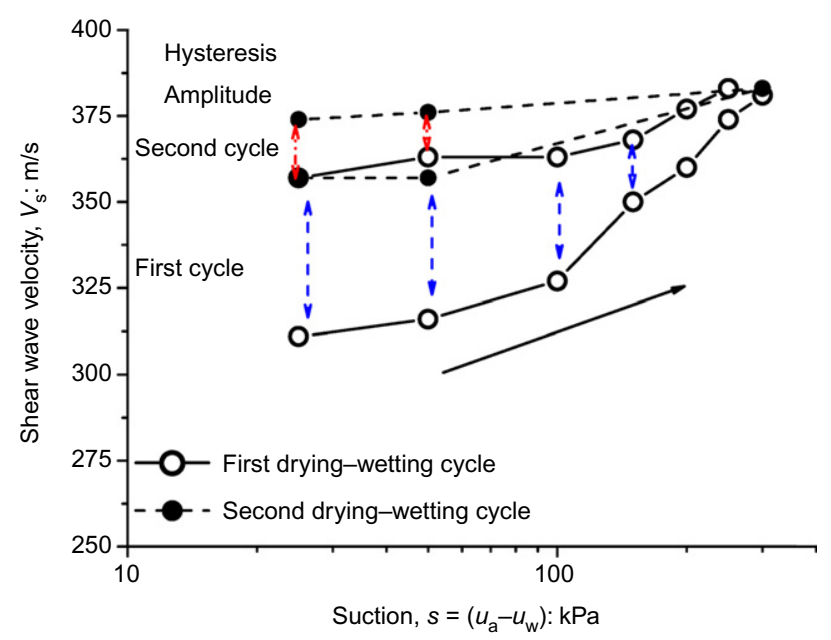

(a)

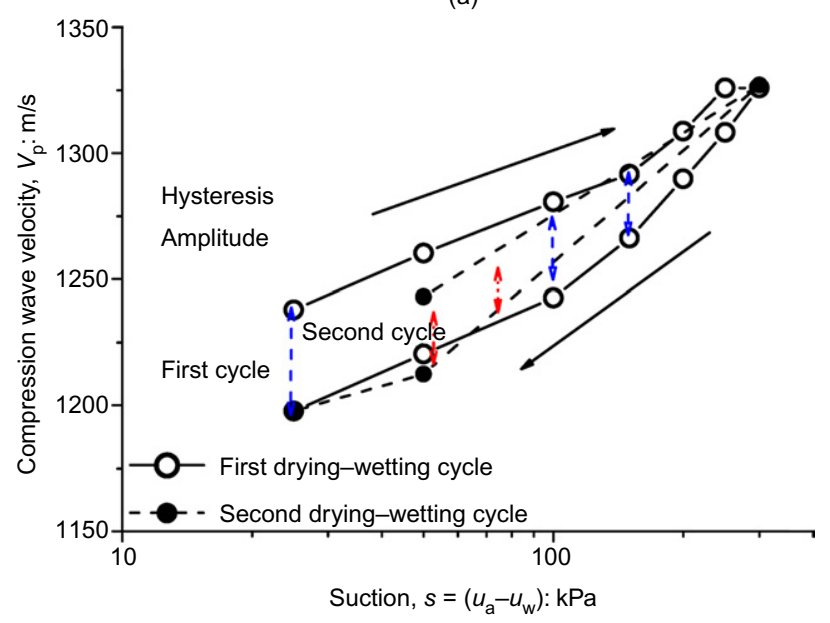

(b)

Fig. 11. Variation of (a) $V_{\mathrm{s}}$ and (b) $V_{\mathrm{p}}$ with suction for multiple drying-wetting paths of a specimen prepared at energy level $530 \mathrm{~kJ} / \mathrm{m}^{3}$ 
to the SWRC response (Fig. 8), but this was not the case. This was possibly due to changes in the soil structure. Koliji et al. (2010) reported that in the high suction range the volume of aggregations are reversible, whereas at low suction upon following the wetting paths it showed fewer distinguishable aggregations. Aggregations refer to the nature of the compacted soil macrostructure. Typically, compacted soil exhibits an aggregation-dominated macrostructure on the dry side and matrix-dominated on the wet side of the OMC (e.g. Delage et al., 1996; Romero \& Simms, 2008). Furthermore, the small strain hysteresis amplitude progressively decreases for an increasing number of drying and wetting cycles, which probably indicates that the soil experiences irrecoverable structural changes and the pore size distribution gradually becomes more uniform (i.e. Pham et al., 2005). Interestingly, $V_{\mathrm{p}}$ was the same for $300 \mathrm{kPa}$ level of suction, despite having a lower degree of saturation in the second cycle. This shows that in this cycle the stiffness of the soil skeleton may govern the propagation of both $V_{\mathrm{s}}$ and $V_{\mathrm{p}}$. Furthermore, not only are the current suction and degree of saturation important, the suction history as represented by the number of drying and wetting cycles also affected the elastic response of the compacted materials.

The variation of Poisson ratio $(v)$ computed using equation (5) is shown in Fig. 12. While for the energy levels of 530 and $838 \mathrm{~kJ} / \mathrm{m}^{3}$ the Poisson ratio seemed to be approximately constant during drying-wetting processes, there were some differences for the specimen compacted at a lower energy level (i.e. $E=243 \mathrm{~kJ} / \mathrm{m}^{3}$ ) and for the specimen prepared at water content of $9.8 \%$. These observations are consistent with the earlier interpretation of a progressive change in the soil structure that probably occurred during the dryingwetting processes. Furthermore, while Poisson ratio still showed small variations in the first drying-wetting cycle for an energy level of $530 \mathrm{~kJ} / \mathrm{m}^{3}$, it remained relatively unchanged for the second drying and wetting cycle.

\section{Shear, constrained and elastic moduli at small strain level}

In Figs 13(a)-13(c), the shear modulus $\left(G_{0}\right)$, constrained modulus $\left(M_{0}\right)$ and elastic modulus $\left(E_{0}\right)$ at a small strain level were plotted against the current suction ratio (CSR). $\mathrm{Ng} \&$ $\mathrm{Xu}$ (2012) reported that the mechanical response, particularly the small strain shear modulus, can be affected by CSR, which can be defined as

$$
\mathrm{CSR}=\frac{s_{\max }}{s_{\text {current }}}
$$

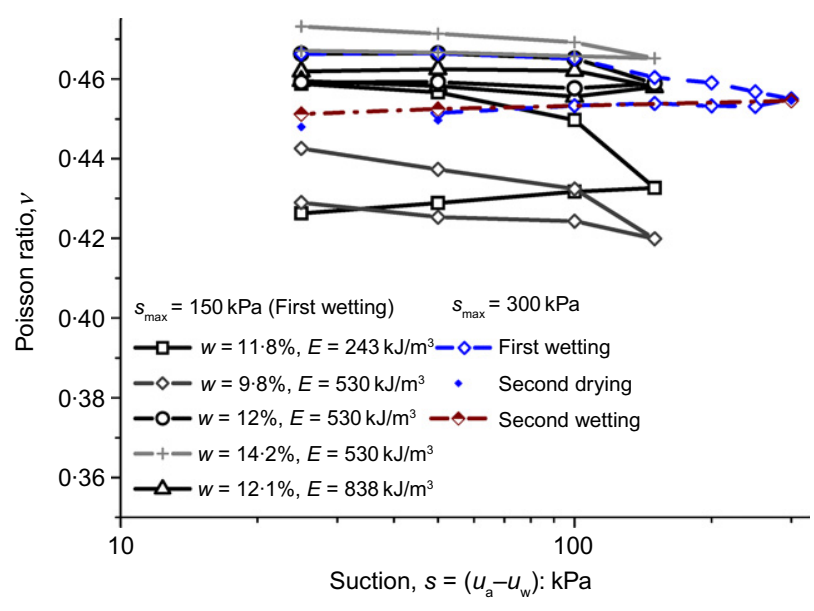

Fig. 12. Variation of the Poisson ratio with suction during dryingwetting cycles of specimens prepared at energy levels of $243 \mathrm{~kJ} / \mathrm{m}^{3}$, $530 \mathrm{~kJ} / \mathrm{m}^{3}$ and $838 \mathrm{~kJ} / \mathrm{m}^{3}$ where $s_{\max }$ is the maximum suction the specimen has been exposed to and $s_{\text {current }}$ is the current suction level. As expected, the specimens compacted with a higher energy level yield larger $G_{0}, M_{0}$ and $E_{0}$ at any given CSR, although there were noticeable differences in $M_{0}$ among the different energy levels. This was likely related to the amount of water, as reflected by the degree of saturation, of the specimens following the wetting paths, that is $S_{\mathrm{r}}=0.7-0.72$ (Fig. 8) for the energy of $243 \mathrm{~kJ} / \mathrm{m}^{3}$ and $S_{\mathrm{r}}=0 \cdot 85-0.88$ (Fig. 8) for energy levels of 530 and $838.4 \mathrm{~kJ} / \mathrm{m}^{3}$, respectively. The first drying-wetting cycle of the CSR values for the drying paths were not shown because the CSR was constant and equal to unity along the drying paths. The specimen subjected to a larger variation of suction $\left(s_{\max }=300 \mathrm{kPa}\right)$ and multiple drying-wetting cycles is also included for comparison. As expected for a given CSR, the elastic moduli $\left(G_{0}, M_{0}\right.$ and $\left.E_{0}\right)$ for the specimen subjected to a larger interval of suction $\left(s_{\max }=300 \mathrm{kPa}\right)$ are higher than those obtained from the specimen subjected to a suction of $150 \mathrm{kPa}$. This is because the current suction was higher (i.e. for $\mathrm{CSR}=3$, the current suction was $150 \mathrm{kPa}$ and $50 \mathrm{kPa}$ for the specimens subjected to a maximum suction of 300 and $150 \mathrm{kPa}$, respectively). Nonetheless, even with the same current suction (i.e. $25 \mathrm{kPa}$ ) the specimens' moduli increased significantly for a higher CSR. Furthermore, even for the same CSR, the elastic moduli seem to be affected by the number of cycles of wetting-drying. For instance, at a suction of $25 \mathrm{kPa}(\mathrm{CSR}=12)$, the $G_{0}, M_{0}$ and $E_{0}$ differed by $25.4 \mathrm{MPa}, 0.95 \mathrm{GPa}$ and $5 \mathrm{MPa}$, respectively, between the first and second cycle. Interestingly, for the same CSR the $M_{0}$ for the specimen subjected to a larger suction interval $\left(s_{\max }=300 \mathrm{kPa}\right)$ was higher despite having a lower degree of saturation (i.e. $S_{\mathrm{r}}=0.78-0.82$, Fig. 8). This further emphasises the role of suction history on the elastic response of the compacted specimens.

To better illustrate the suction stress history at different CSRs on $G_{0}, M_{0}$ and $E_{0}$, the data normalised by the current stress state $\left(p^{*}\right)$ were replotted in Figs 13(d)-13(f). The current stress state $\left(p^{*}\right)$ can be represented by a function of the isotropic net confining pressure $\left(p-u_{\mathrm{a}}\right)$, suction $\left(u_{\mathrm{a}}-u_{\mathrm{w}}\right)$ and degree of saturation $\left(S_{\mathrm{r}}\right)$, as follows

$$
p^{*}=\left[\left(p-u_{\mathrm{a}}\right)+\left(u_{\mathrm{a}}-u_{\mathrm{w}}\right) S_{\mathrm{r}}\right]
$$

The current stress (equation (9)) for the different compacted specimens and suction levels is given also in Table 2. The advantage of using the above relationship is that the current suction and degree of saturation (also known as effective suction), as well as the current net confining stress, are adequately accounted for in the moduli response. The justification for the inclusion of the degree of saturation in the expression of the stress state lies with the observations of the variation of $V_{\mathrm{s}}$ in wetting and drying cycles. For a given suction level, the $V_{\mathrm{s}}$ changes upon drying and wetting. This means that if the stress state is defined solely on the basis of net stress and matric suction, the observed $V_{\mathrm{s}}$ or $G_{0}$ behaviour cannot be captured. In addition, the current stress state represented in this manner is consistent with the Bishop type effective stress description widely used for partially saturated soils (e.g. Bishop, 1959; Mancuso et al., 2002; Tarantino \& El Mountassir, 2013).

In fact, Figs 13(d)-13(f) show that the normalised elastic moduli increased with the CSR. Furthermore, it seems that a logarithm relationship can represent the variation of the normalised moduli with CSR and different energy levels define a unique line with the exception of the specimen prepared at water content of $14 \cdot 2 \%\left(E=530 \mathrm{~kJ} / \mathrm{m}^{3}\right)$. This implies that the elastic response was relatively independent of the compaction energy level $\left(s_{\max }=150 \mathrm{kPa}\right)$ in the normalised moduli-CSR plane, which is of great practical 


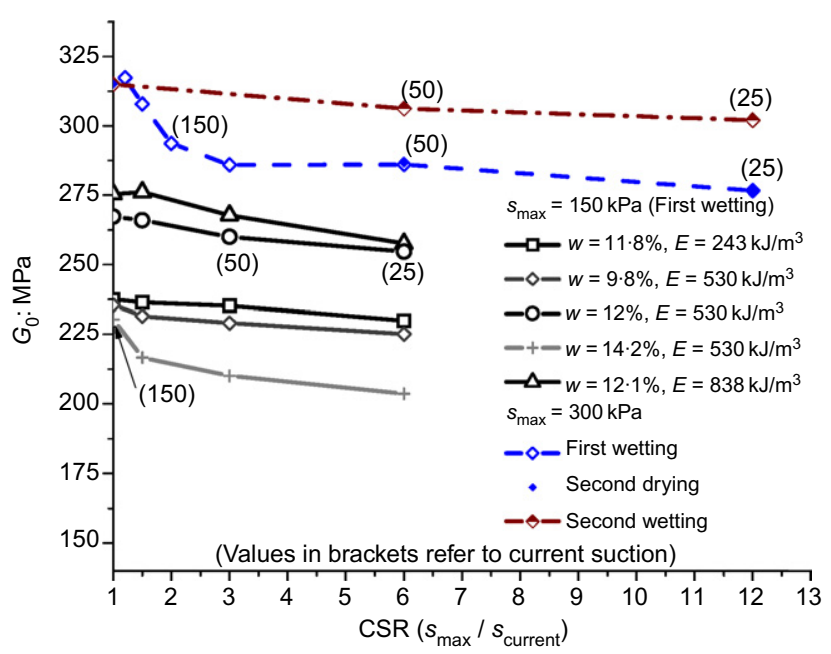

(a)

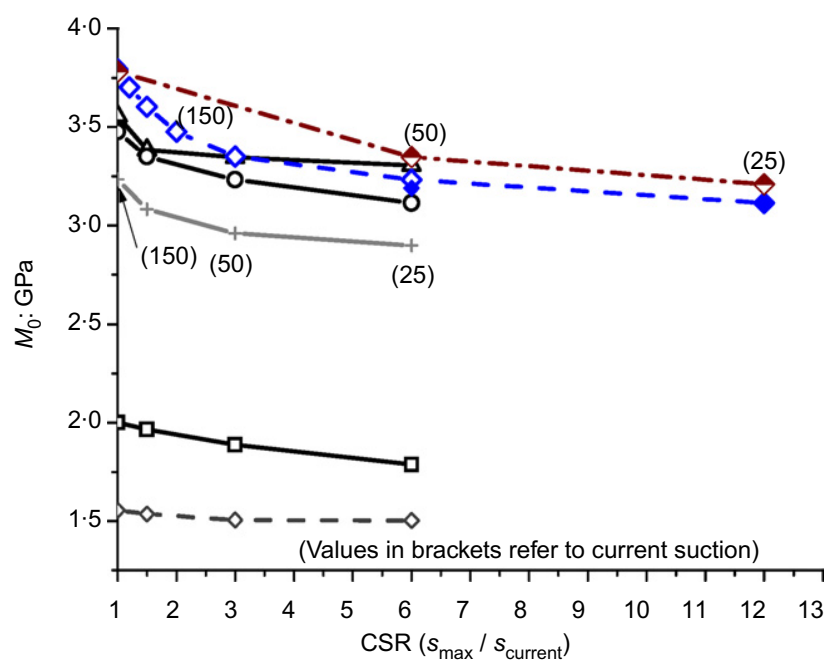

(c)

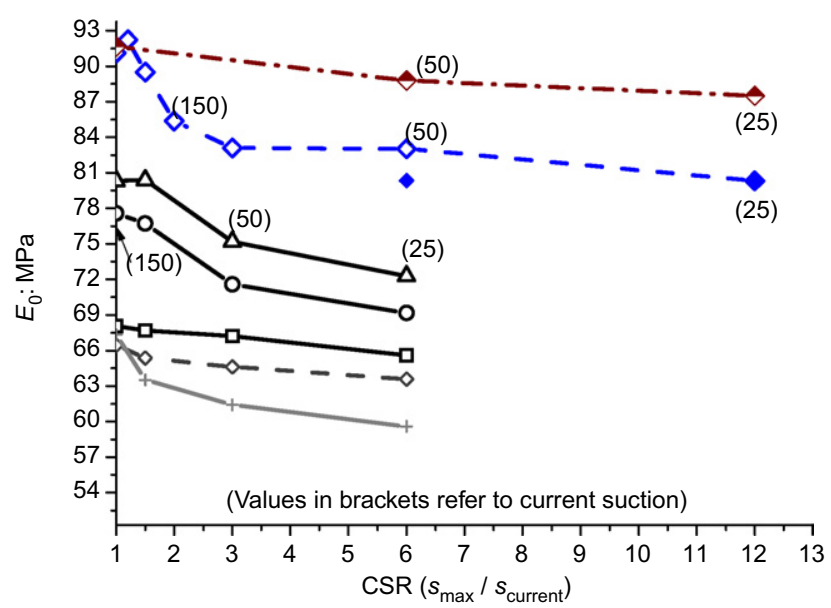

(e)

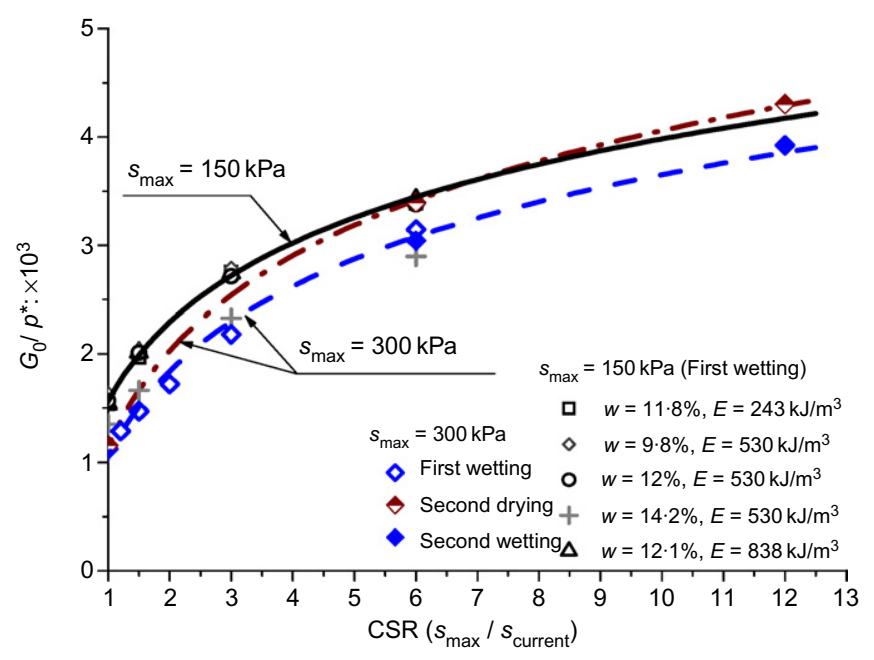

(b)

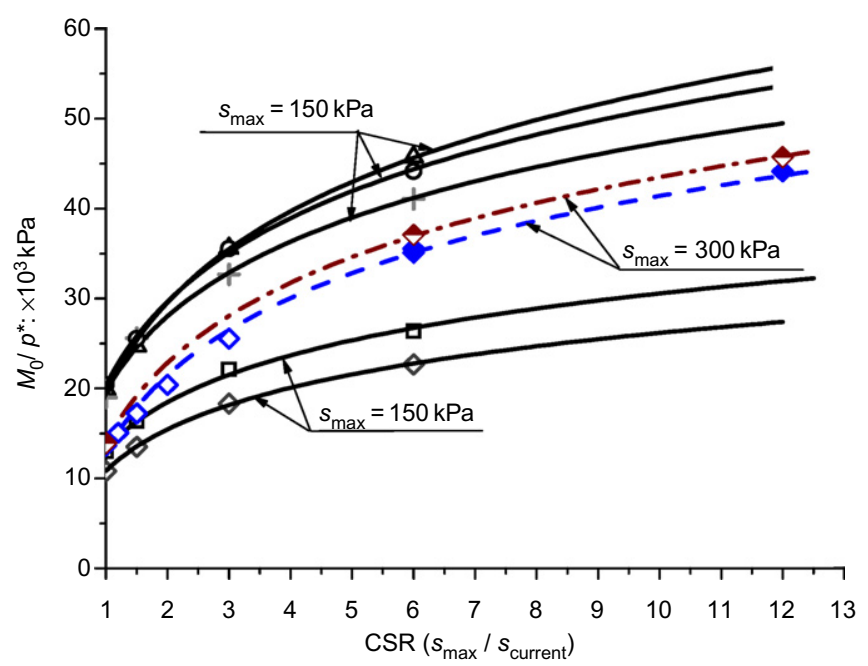

(d)

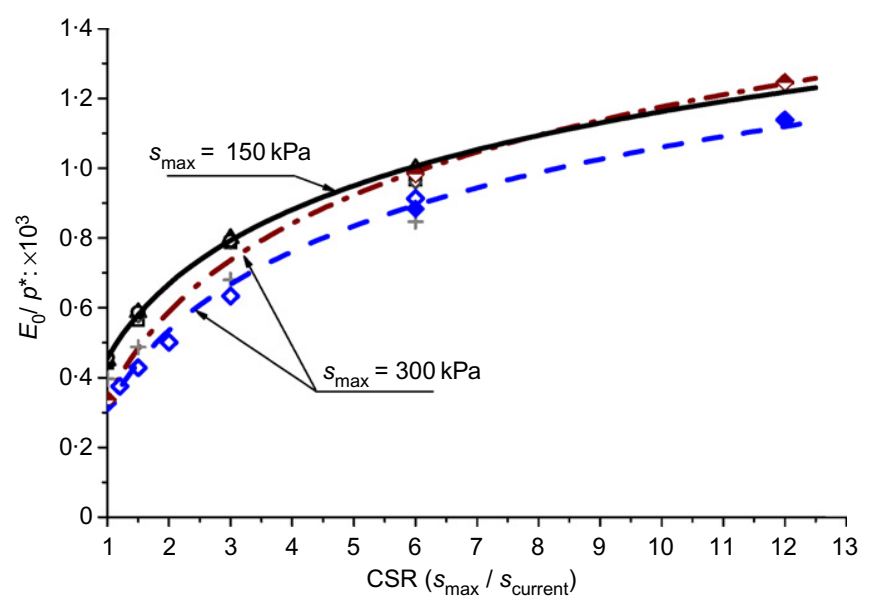

(f)

Fig. 13. Variation of $G_{0}, M_{0}$ and $E_{0}$ with current suction ratio (CSR) for the wetting paths of specimens prepared at energy levels of $243 \mathrm{~kJ} / \mathrm{m}^{3}$, $530 \mathrm{~kJ} / \mathrm{m}^{3}$ and $838 \mathrm{~kJ} / \mathrm{m}^{3}$

significance during the time of placement because the prescribed energy level is often not defined in common end-product specifications (AS 3798 (SA, 2007)). These results suggest that $G_{0} / p^{*}$ and $E_{0} / p^{*}$ may be predicted for any energy level following constant water content paths provided the suction history is similar The only exception is the variation of $M_{0} / p^{*}$ (Fig. 13(e)), which showed some differences between the three different energy levels, possibly related to the large dependence of the bulk modulus of the material.

For the same CSR, the $G_{0} / p^{*}, M_{0} / p^{*}$ and $E_{0} / p^{*}$ values in the first wetting of the specimen that experienced a maximum suction of $300 \mathrm{kPa}$ were consistently lower than those subjected to a maximum suction of $150 \mathrm{kPa}$. However, the values of $G_{0} / p^{*}, M_{0} / p^{*}$ and $E_{0} / p^{*}$ increased in the subsequent number of cycles, which indicates that the soil skeleton was 
Table 2. Current stress for different suction levels (drying-wetting cycle)

\begin{tabular}{l|c|c|c|c|c}
\hline $\begin{array}{l}\text { Suction } \\
\text { level: kPa }\end{array}$ & \multicolumn{5}{|c}{$p^{*}: \mathrm{kPa}$} \\
\hline & $11-12$ & $24-12$ & $38-12$ & $24-10$ & $24-14$ \\
25 & $69 \cdot 8$ & $72 \cdot 6$ & $73 \cdot 2$ & $67 \cdot 25$ & $72 \cdot 25$ \\
50 & $88 \cdot 5$ & $94 \cdot 8$ & $96 \cdot 27$ & $83 \cdot 5$ & $93 \cdot 5$ \\
100 & $123 \cdot 1$ & $138 \cdot 1$ & $139 \cdot 6$ & 113 & 134 \\
150 & $153 \cdot 9$ & $178 \cdot 5$ & $178 \cdot 9$ & $138 \cdot 5$ & 170 \\
100 & $120 \cdot 1$ & $136 \cdot 5$ & $137 \cdot 1$ & 110 & $130 \cdot 5$ \\
50 & $85 \cdot 4$ & $93 \cdot 3$ & $94 \cdot 1$ & $80 \cdot 5$ & $90 \cdot 75$ \\
25 & $67 \cdot 8$ & $71 \cdot 8$ & $72 \cdot 25$ & $65 \cdot 5$ & $70 \cdot 5$ \\
\hline
\end{tabular}

Note: $p^{*}$ refers to the current stress expressed in equation (9).

strengthened with the number of drying and wetting cycles, which may be attributed to the effect of suction history and some form of hydraulic ageing.

\section{CONCLUSIONS}

From a number of bender-extender element tests conducted in specimens compacted at three different energy levels and then subjected to a post-compaction cycle of drying and wetting, the effect of variations in suction on small strain stiffness was significant. Larger values of $V_{\mathrm{s}}$ and associated $G_{0}$ corresponded to the wetting paths, a difference that was associated with the water retention properties. Furthermore, the response of $V_{\mathrm{p}}$ and $M_{0}$ depended mainly on the bulk modulus or the volume of water present because they both had lower values on the wetting paths. The initial dry unit weight and associated soil structure that resulted from preparing the specimens at different energy levels had a strong influence on the amplitude of the hysteretic response observed in a drying-wetting cycle, particularly for the $V_{\mathrm{s}}$ and associated $G_{0}$ behaviour. Larger hysteresis amplitudes were observed for specimens compacted at lower energy levels, which indicated that poorly compacted conditions can influence the post-compacted mechanical response. The suction history defined by the CSR appeared to control the elastic moduli $\left(G_{0}, M_{0}\right.$ and $\left.E_{0}\right)$ to some extent but the energy level contributed to an increase in the moduli for the same CSR. However, these differences are mainly related to the current stress state because a common relationship between normalised $G_{0} / p^{*}$ and $E_{0} / p^{*}$, and CSR can be obtained for different energy levels. The suction history path had a significant effect on the small strain responses, particularly for subsequent drying and wetting cycles. Finally, this study shows that the geomechanical behaviour of earth structures can be affected when exposed to changes in hydraulic regimes. This should be considered when evaluating longterm performance, particularly where fills are inadequately compacted.

\section{ACKNOWLEDGEMENTS}

The authors acknowledge the financial assistance provided by the Australia Research Council, Penrith Lakes Development Corporation, Ltd and Coffey Geotechnics. Assistance from Mr Robert Golaszewski, Mr Alan Grant and $\mathrm{Mr}$ Ian Laird is gratefully acknowledged.

\section{NOTATION}

$E$ compaction energy level

$E_{0} \quad$ small strain elastic modulus

$f$ frequency

$G_{0} \quad$ small strain shear modulus g gravity acceleration

$H_{\mathrm{s}}$ depth of moisture change

$L_{\mathrm{tt}} \quad$ tip-to-tip distance

$L_{\mathrm{tt}-\mathrm{i}}$ initial tip-to-tip distance or wave path length

$l_{\mathrm{b}}$ bender elements cantilevered length

$M_{0} \quad$ small strain constrained modulus

$n$ porosity

$p^{*} \quad$ current stress state

$p-u_{\mathrm{a}}$ net confining pressure

$S_{\mathrm{r}}$ degree of saturation

$s$ suction, or also represented by $\left(u_{\mathrm{a}}-u_{\mathrm{w}}\right)$

$s_{\text {current }}$ current suction

$s_{\max }$ maximum suction the specimen has been exposed to

$t$ time

$u_{\mathrm{a}}$ pore air pressure

$u_{\mathrm{w}}$ pore water pressure

$V_{\mathrm{p}}$ compression wave velocity

$V_{\mathrm{s}}$ shear wave velocity

$w$ water content

$\gamma_{\mathrm{b}}$ bulk unit weight

$\gamma_{\mathrm{d}}$ dry unit weight

$\gamma_{\mathrm{w}} \quad$ water unit weight

$\Delta t_{\mathrm{s}} \quad$ shear wave travel time

$\Delta t_{\mathrm{p}} \quad$ compression wave travel time

$\Delta V_{\mathrm{w}} \quad$ volume of water change

$\lambda$ wave length

$v$ Poisson ratio

$\rho_{\mathrm{a}}$ density of the gas (air)

\section{REFERENCES}

Arulnathan, R., Boulanger, R. W. \& Riemer, M. F. (1998). Analysis of bender element tests. Geotech. Testing J. 21, No. 2, 120-131.

ASTM (2003). D 5298: Standard test method for measurement of soil potential (suction) using filter paper method. West Conshohocken, PA, USA: ASTM International.

ASTM (2004). D 3404-91: Standard guide for measuring matric potential in the vadose zone using tensiometers. West Conshohocken, PA, USA: ASTM International.

Austroads (2004). Impact of climate change on road infrastructure, AP-R243. Sydney, Australia: Ausroads.

Bagherieh, A. R., Khalili, N., Habibagahi, G. \& Ghahramani, A. (2009). Drying response and effective stress in a double porosity aggregated soil. Engng Geol. 105, No. 1, 44-50.

Barrière, J., Bordes, C., Brito, D., Sénéchal, P. \& Perroud, H. (2012). Laboratory monitoring of $\mathrm{P}$ waves in partially saturated sand. Geophys. J. Int. 191, No. 3, 1152-1170.

Biglari, M., d'Onofrio, A., Mancuso, C., Jafari, M. K., Shafiee, A. \& Ashayeri, I. (2012). Small-strain stiffness of Zenoz kaolin in unsaturated conditions. Can. Geotech. J. 49, No. 3, 311-322.

Bishop, A. W. (1959). The principle of effective stress. Teknisk Ukeblad 106, No. 39, 859-863.

Cho, G. C. \& Santamarina, J. C. (2001). Unsaturated particulate materials - particle level studies. J. Geotech. Geoenviron. Engng 127, No. 1, 84-96.

Clayton, C. R. I. (2011). Stiffness at small strain: research and practice. Géotechnique 61, No. 1, 5-37, http://dx.doi. org/10.1680/geot.2011.61.1.5.

Cuisinier, O. \& Laloui, L. (2004). Fabric evolution during hydromechanical loading of a compacted silt. Int. J. Numer. Analyt. Methods Geomech. 28, No. 6, 483-499.

Delage, P., Audiguier, M., Cui, Y. J. \& Howat, M. D. (1996). Microstructure of a compacted silt. Can. Geotech. J. 33, No. 1, $150-158$.

Fityus, S. \& Buzzi, O. (2008). On the use of the Thornwaite moisture index to infer depths of seasonal moisture change. Aust. Geomech. 43, No. 4, 69-76.

George, L. A., Dewoolkar, M. M. \& Znidarcic, D. (2009). Simultaneous laboratory measurement of acoustic and hydraulic properties of unsaturated soils. Vadose Zone J. 8, No. 3, 633-642.

Heitor, A., Indraratna, B. \& Rujikiatkamjorn, C. (2012). Characterising compacted soil using shear wave velocity and matric suction. Aust. Geomech. J. 47, No. 2, 79-86. 
Heitor, A., Indraratna, B. \& Rujikiatkamjorn, C. (2013). Laboratory study of small-strain behavior of a compacted silty sand. Can. Geotech. J. 50, No. 2, 179-188.

Inci, G., Yesiller, N. \& Kagawa, T. (2003). Experimental investigation of dynamic response of compacted clayey soils. Geotech. Testing J. 26, No. 2, 125-141.

Khosravi, A. \& McCartney, J. S. (2012). Impact of hydraulic hysteresis on the small-strain shear modulus of low plasticity soils. J. Geotech. Geoenviron. Engng 138, No. 11, 1326-1333.

Koliji, A., Vulliet, L. \& Laloui, L. (2010). Structural characterization of unsaturated aggregated soil. Can. Geotech. J. 47, No. 3, $297-297$.

Lee, J. S. \& Santamarina, J. C. (2005). Bender elements: performance and signal interpretation. J. Geotech. Geoenviron. Engng 131, No. 9, 1063-1070.

Leong, E. C., Yeo, S. H. \& Rahardjo, H. (2005). Measuring shear wave velocity using bender elements. Geotech. Testing $J$. 28, No. 5, 1-11.

Leong, E. C., Cahyadi, J. \& Rahardjo, H. (2009). Measuring shear and compression wave velocities of soil using bender-extender elements. Can. Geotech. J. 46, No. 7, 792-812.

Lourenco, S. D. N., Gallipoli, D., Augarde, C. E., Toll, D. G., Fisher, P. C. \& Congreve, A. (2012). Formation and evolution of water menisci in unsaturated granular media. Géotechnique 62, No. 3, 193-199, http://dx.doi.org/10.1680/geot.11.P.034.

Mancuso, C., Vassallo, R. \& d'Onofrio, A. (2002). Small strain behaviour of a silty sand in controlled suction resonant columntorsional shear tests. Can. Geotech. J. 39, No. 1, 22-32.

Marinho, F. A. M., Chandler, R. J. \& Crilly, M. S. (1996). Stiffness measurements on an unsaturated high plasticity clay using bender elements. Proceedings of the 1st international conference on unsaturated soils, Paris, France, vol. 1, pp. $1179-1200$.

Monroy, R., Zdravkovic, L. \& Ridley, A. (2010). Evolution of microstructure in compacted London Clay during wetting and loading. Géotechnique 60, No. 2, 105-119, http://dx.doi. org $/ 10.1680$ /geot.8.P.125.

$\mathrm{Ng}, \mathrm{C}$. W. W. \& Xu, J. (2012). Effects of current suction ratio and recent suction history on small-strain behaviour of an unsaturated soil. Can. Geotech. J. 49, No. 2, 226-243.

$\mathrm{Ng}, \mathrm{C}$. W. W., Xu, J. \& Yung, S. Y. (2009). Effects of wetting-drying and stress ratio on anisotropic stiffness of an unsaturated soil at very small strains. Can. Geotech. J. 46, No. 9, 1062-1076.

Pham, H. Q., Fredlund, D. G. \& Barbour, S. L. (2005). A study of hysteresis models for soil-water characteristic curves. Can. Geotech. J. 42, No. 6, 1548-1568.

Reddy, B. V. \& Jagadish, K. S. (1993). The static compaction of soils. Géotechnique 43, No. 2, 337-341, http://dx.doi.org/10. 1680/geot.1993.43.2.337.

Romero, E. \& Simms, P. (2008). Microstructure investigation in unsaturated soils: a review with special attention to contribution of mercury intrusion porosimetry and environmental scanning electron microscopy. Geotech. Geol. Engng 26, No. 6, 705-722.

SA (Standards Australia) (1996). AS 2870-1996: Residential slabs and footings - construction. Sydney, Australia: Standards Australia.

SA (2003). AS 1289.5.1.1-2003: Method for testing soils for engineering purposes - soil compaction and density tests determination of the dry density/moisture content relation of a soil using standard compactive effort. Sydney, Australia: Standards Australia.

SA (2007). AS 3798: Guidelines on earthworks for commercial and residential developments. Sydney, Australia: Standards Australia.

Sanchez-Salinero, I., Roesset, J. M. \& Stokoe, K. H. (1986). Analytical studies of body wave propagation and attenuation, GR-85-15. Austin, TX, USA: University of Texas.

Sawangsuriya, A., Edil, T. B. \& Bosscher, P. J. (2008). Modulus-suction-moisture relationship for compacted soils. Can. Geotech. J. 45, No. 7, 973-983.

Seed, B. \& Chan, C. K. (1959). Compacted clays: structure and strength characteristics. J. Soil Mech. Found. Div. Trans. 126, No. I, 1344.

Sheng, D. \& Zhou, A. N. (2011). Coupling hydraulic with mechanical models for unsaturated soils. Can. Geotech. J. 48, No. 5, 826-840.

Sridharan, A. \& Sivapullaiah, P. V. (2005). Mini compaction test apparatus for fine grained soils. Geotech. Testing J. 28, No. 3, 1-6.

Tang, A. M., Vu, M. N. \& Cui, Y. J. (2011). Effects of the maximum soil aggregates size and cyclic wetting-drying on the stiffness of a lime-treated clayey soil. Géotechnique 61, No. 5, 421-429, http://dx.doi.org/10.1680/geot.SIP11.005.

Tarantino, A. \& El Mountassir, G. (2013). Making unsaturated soil mechanics accessible for engineers: preliminary hydraulicmechanical characterisation and stability assessment. Engng Geol. 165: 89-104.

Tarantino, A. \& Tombolato, S. (2005). Coupling of hydraulic and mechanical behaviour in unsaturated compacted clay. Géotechnique 55, No. 4, 307-317, http://dx.doi.org/10. 1680/geot.2005.55.4.307.

Thornthwaite, C. W. (1948). An approach toward a rational classification of climate. Soil Sci. 66, No. 1, 77.

Toll, D. G. \& Ong, B. H. (2003). Critical-state parameters for an unsaturated residual sandy clay. Géotechnique 53, No. 1, 93-103, http://dx.doi.org/10.1680/geot.2003.53.1.93.

Vinale, F., D’Onofrio, A., Mancuso, C., Santucci de Magistris, F. \& Tatsuoka, F. (2001). The pre-failure behaviour of soils as construction materials. Proceedings of the 2nd international conference on prefailure deformation characteristics of geomaterials, Torino, Italy, vol. 2, pp. 955-1007. 